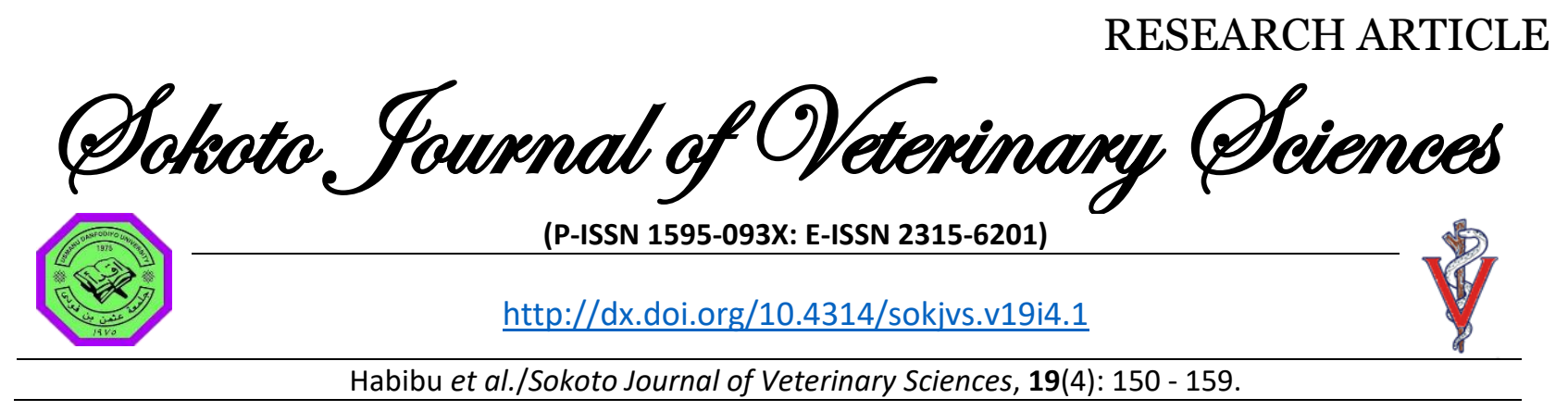

\title{
Endogenous and seasonal factors influencing circulating thyrotropin concentration in Red Sokoto and Sahel goats
}

\author{
B Habibu ${ }^{1 *}$, MU Kawu ${ }^{1}$, T Aluwong ${ }^{1}$, HJ Makun², LS Yaqub ${ }^{1}$, HU Buhari ${ }^{3}$ \& A \\ Saleh $^{4}$ \\ 1. Department of Veterinary Physiology, Ahmadu Bello University, Zaria, Nigeria \\ 2. Small Ruminant Research Programme, National Animal Production Research Institute, Ahmadu Bello University, \\ Zaria, Nigeria \\ 3. Samaru College of Agriculture, Division of Agricultural Colleges, Ahmadu Bello University, Zaria, Nigeria \\ 4. Department of Veterinary Pathology, Ahmadu Bello University, Zaria, Nigeria
}

*Correspondence: Tel.: +2348072417784; E-mail: buharihabibu@rocketmail.com

\begin{abstract}
Copyright: (c) 2021
Habibu et al. This is an

open-access article published under the terms of the Creative Commons Attribution License which permits unrestricted use, distribution, and reproduction in any medium, provided the original author and source are credited.
\end{abstract}

Publication History: Received: 09-02-2021 Revised: 19-04-2021 Accepted: 12-05-2021

\section{Abstract}

Through regulating thyroid physiology, thyrotropin influences the activities of thyroid hormones, including thermogenesis and adaptation to ambient thermal challenges. This study aimed at evaluating the influences of some endogenous factors (breed, sex, age and body mass index; $\mathrm{BMI}$ ) and season on circulating thyrotropin concentration in Red Sokoto and Sahel goats. A total of 120 goats were sampled, comprising Red Sokoto $(n=$ $20)$ and Sahel $(n=20)$ goats in each season during the peak of the cold-dry (CDS), hotdry (HDS) and rainy (RAS) seasons in a tropical Savannah climate. Results revealed that among Red Sokoto goats, bucks had significantly higher $(\mathrm{P}<0.05)$ circulating thyrotropin concentration than does during the HDS, while adults had significantly higher values than kids during the RAS. Significant $(\mathrm{P}<0.05)$ breed difference was only observed during the HDS, with the Red Sokoto goats having higher values among adult bucks and doelings but lower values than Sahel goats among buck-kids and adult does. Significant $(\mathrm{P}<0.05)$ seasonal variation was observed only in male Sahel goats with buck-kids having lower values during RAS as compared with CDS and HDS, while adult bucks had higher values during the RAS as compared with the HDS. A significant positive correlation $(r=$ $0.29 ; \mathrm{P}<0.001$ ) was observed between thyrotropin concentration and $\mathrm{BMI}$ in the overall population. It was concluded that circulating thyrotropin concentration was higher in male and adult goats, and the effects of season and breed were sex and age-dependent. Moreover, the direct relationship between thyrotropin concentration and BMI may reflect the role of thyrotropin in the accumulation of body energy reserve in the savannah goats.

Keywords: Age, Breed, Body mass index, Sex, Thyroid-stimulating hormone

\section{Introduction}

One livestock product from Northern Nigerian with great economic value that attracted global attention during the colonial era was the skin of the Red Sokoto goat (RSG), exported as the famous Morocco leather. 
It acquired this name because it was transported across the Sahara by caravans controlled by Moroccan merchants (Adebayo, 1992; Blench, 1999). For this reason, the SRSG is described as 'the most famous African goat that no one has heard of'. On the other hand, the Sahel goat, which is also a Savannah goat type like the Red Sokoto goat, has been described as the sheep-like breed of goat, found in the Sahel belt of West Africa, as it is distributed from Senegal to Sudan (Blench, 1999). All year-round, goats and other livestock inhabiting some regions of West African, including the Northern Guinea Savannah, experience a combination of environmental conditions which have been classified into three major seasons, namely: the cold-dry (harmattan; CDS), hot-dry (HDS) and rainy (RAS) seasons (Igono \& Aliu, 1982; Habibu et al., 2017). The challenge of the CDS is the cold-dry wind, heavy dust-laden particles, and wide fluctuations in day and night ambient temperatures, while that of the HDS is the high ambient temperatures that predispose livestock to heat stress (Minka \& Ayo, 2014; Habibu et al., 2017; Sejian et al., 2019).

Thyrotropin or thyroid-stimulating hormone (TSH) is a pituitary hormone that influences most activities of thyroid hormones by binding to the TSH receptors in the thyroid gland to induce the release of thyroxine $\left(T_{4}\right)$ and a limited amount of tri-iodothyronine $\left(T_{3}\right.$; Klein, 2019; Ertek, 2021). Besides, this basic function, TSH has been linked to obesity in humans and immune system in humans and mice (Smith et al., 1983; Kruger et al., 1989; Bell et al., 2000; Valyasevi et al., 2002; Al-Musa, 2017; Klein, 2019). Seasonality in circulating $T_{3}$ and $T_{4}$ in goats is physiologically manipulated to maintain body temperature within normal range, irrespective of season (Habibu et al., 2016a). Circulating $T_{3}$ and $T_{4}$ has been reported to be higher in Red Sokoto than Sahel goat kids (Habibu et al., 2016a; Sejian et al., 2019). Similarly, circulating $T_{3}$ and $\mathrm{T}_{4}$ have been shown to be higher in growing goats than adults, while does have higher values than bucks (Colavita et al., 1983; Todini et al., 1992; Todini, 2007). Probably, due to the anabolic effect of $T_{3}$ and $\mathrm{T}_{4}$ on protein synthesis, especially in growing subjects (Capen \& Martin, 2003), the correlation between body mass index (BMI) and both $\mathrm{T}_{3}$ and $\mathrm{T}_{4}$ was positive in goats (Habibu et al., 2016a). While the influences of breed, sex, age, BMI and season on circulating $T_{3}$ and $T_{4}$ have been well reported in goats (Todini et al., 1992; Todini, 2007; Habibu et al., 2016a; 2017), there is a paucity of information on the influence of these factors on TSH in goats. This is despite the fact that circulating $T_{3}$ and $T_{4}$ are under the influence of TSH (Todini, 2007). Understanding how breed, sex, age, BMI and season collectively influence both thyroid hormones and TSH may significantly complement the existing knowledge on the mechanism through which different breeds, sexes and age groups of livestock cope with seasonal changes. The aim of this study was to evaluate the influences of breed, sex, age, BMI and season on circulating TSH concentrations in Red Sokoto and Sahel goats.

\section{Materials and Methods}

\section{Experimental site and animal management}

The study was carried out in the Small Ruminant Research Section of the National Animal Production Research Institute (NAPRI), Ahmadu Bello University, Shika, Zaria, Nigeria, and located on latitude $11^{\circ} 12^{\prime}$ $\mathrm{N}$, longitude $7^{0} 33^{\prime} \mathrm{E}$ and an altitude of $610 \mathrm{~m}$ above sea level. The goats were housed in a half-walled pen, roofed with galvanized metal sheet, and the floor was covered with concrete. The pens were well-ventilated and had dimensions of $6.1,6.1$ and $2.2 \mathrm{~m}$ for length, width and height, respectively. The pens had a stocking density of 35 kids. The health status of the goats was evaluated based on behaviour, appetite and faecal consistency. Routinely, the goats were screened by a trained staff member for haemoparasites and helminths (using floatation and sedimentation tests). Only clinically healthy animals were used for the study. Both breeds of goat were housed within the same environment. Oestrous synchronisation of the does for breeding was carried out using controlled internal drug release (CIDR) and the bucks were allowed to mate the does naturally. The kids were provided with milk by directly suckling their dams and weaned at 3 months of age. The adult goats were fed on Digitaria smutsi hay as a basal diet. All the goats were supplemented with a concentrate ration of ground maize (30\%), cottonseed cake (36\%), maize offal $(20 \%)$, wheat offal $(10 \%)$, bone meal $(2.5 \%)$ and salt $(1.5 \%)$ at $3 \%$ body weight per day. Good-quality drinking water was provided ad libitum.

\section{Experimental design}

The adult Red Sokoto and Sahel goats used for the study were homogeneous for age (4 to 5 years), live weight $(25 \pm 1.6 \mathrm{~kg})$ and body condition score $(2.9 \pm$ 0.1 . The age of kids for both breeds ranged between 2 to 4 months. Body condition was scored by the same person adopting a six-point scale method (Santucci et al., 1991). The goat kids were sampled at the peak of the CDS, HDS and RAS during the months of December, April and July, respectively. A total of 120 
goats were used in the study. In each season, 40 different sets of goats (20 goats from each of the two breeds) of both sexes were sampled. For each of the breeds, five $(n=5)$ goats of different sexes (buck and does) and age groups (adults and kids) were used in every season. Five millilitres $(5 \mathrm{ml})$ of blood sample was obtained from each goat in the morning hours, between 09:00 and 11:00 h (GMT + 1), through the jugular vein into vacutainer tubes containing potassium ethylenediaminetetraacetic acid. The adapted study protocol and animal experimentation followed the international guidelines for animal welfare.

Morphometric dimensions of the goats for the determination of BMI were obtained using a measuring tape. Body length was measured as the length from the external occipital protuberance to the base of the tail, while withers height was measured as the length from the surface of a platform to the withers as described by Hassan \& Ciroma (1992). Body mass index was then determined using the mathematical formula described by Tanaka et al. (2003):

BMI = Body Weight $(\mathrm{kg}) /$ WWithers Height $(\mathrm{m}) /$ Body Length $(m) \times 10\}$

Values of ambient temperature and relative humidity in the morning and afternoon hours of the study period were obtained from the Meteorological Unit, Institute of Agricultural Research, Ahmadu Bello University, Zaria, Nigeria; located about $6 \mathrm{~km}$ away from the experimental site. The temperaturehumidity index (THI) was then calculated (Ravagnolo et al., 2000): $\mathrm{THI}=(1.8 \times \mathrm{T}+32)-\{(0.55-0.0055 \bullet$ $\mathrm{RH}) \times(1.8 \times \mathrm{T}-26)\}$; where: $\mathrm{T}=$ ambient temperature $\left({ }^{\circ} \mathrm{C}\right)$ and $\mathrm{RH}=$ relative humidity $(\%)$.
Concentrations of circulating TSH were determined from the serum using a commercial enzyme-linked immunoassay kit (AccuBind ELISA Microwells; Monobind Inc ${ }^{\circledR}$ California, USA). Assay sensitivity was $0.078 \mu \mathrm{IU} / \mathrm{mL}$ and the intra-assay coefficients of variation for normal levels of TSH were less than $10 \%$. All assays were performed following the manufacturer's instructions.

\section{Data analysis}

The statistical package used was GraphPad Prism version 5.01 for windows (2007) from GraphPad Software, San Diego California, USA. Values obtained were expressed as mean ( \pm SEM). The 3rd and 97th percentiles were calculated as the of circulating TSH because of the skewed data distribution. Comparisons between breeds and sexes were done using Student's t-test, while one-way analysis of variance, followed by Tukey's post hoc test were used to compare values among the seasons. Values of $P<$ 0.05 were considered significant.

\section{Results}

The mean values of meteorological parameters in the study area are presented in Table 1 . The highest $(\mathrm{P}<$ 0.05) mean ambient temperature and THI were recorded during the afternoon hours of the HDS. While the highest $(P<0.05)$ relative humidity was recorded during the RAS in the morning hours, the lowest $(P<0.05)$ THI was recorded in the morning hours of the CDS.

The normal range of TSH concentrations in Red Sokoto and Sahel goats are presented in Table 2. The overall mean values of TSH concentrations in Red Sokoto tended to be lower $(P=0.13)$ than that of Sahel goats ( 0.76 vs $0.82 \mu \mathrm{lU} / \mathrm{ml}$ ). Similarly, the

Table 1: Mean values of meteorological parameters during the cold-dry, hot-dry and rainy seasons

\begin{tabular}{lcccccc}
\hline Parameters & \multicolumn{2}{c}{ Cold-dry } & \multicolumn{2}{c}{ Hot-dry } & \multicolumn{2}{c}{ Rainy } \\
\cline { 2 - 7 } & Morning & Afternoon & Morning & Afternoon & Morning & Afternoon \\
\hline Ambient Temperature $\left({ }^{\circ} \mathrm{C}\right)$ & 17.45 & $29.12^{\mathrm{x}}$ & 25.00 & $39.11^{y}$ & 23.30 & $30.79^{\mathrm{x}}$ \\
Relative Humidity (\%) & 20.06 & 16.23 & 49.99 & 25.51 & 76.61 & 71.42 \\
THI & $56.96^{\mathrm{x}}$ & $73.13^{\mathrm{x}}$ & $70.97^{y}$ & $85.21^{y}$ & $71.21^{y}$ & $80.31^{y}$ \\
\hline
\end{tabular}

Values with different superscript $(x, y)$ indicate significant $(P<0.05)$ difference between seasons. $\mathrm{THI}=$ temperaturehumidity index

Table 2: Normal range of TSH ( $\mu \mathrm{lU} / \mathrm{ml})$ in the goats studied

\begin{tabular}{lcccccccc}
\hline & Mean \pm SEM & Median & Min-Max & P3 & P97 & Skewness & Kurtosis & Range \\
\hline RSG & $0.76 \pm 0.02$ & 0.72 & $0.17-1.61$ & 0.50 & 1.50 & 1.69 & 5.23 & $0.50-1.50$ \\
SG & $0.82 \pm 0.03$ & 0.72 & $0.51-1.9$ & 0.51 & 1.56 & 1.74 & 3.04 & $0.51-1.56$ \\
Total & $0.79 \pm 0.02$ & 0.72 & $0.17-1.90$ & 0.51 & 1.50 & 1.79 & 4.12 & $0.51-1.50$ \\
\hline
\end{tabular}

RSG - Red Sokoto Goat; SG - Sahel Goat 
A

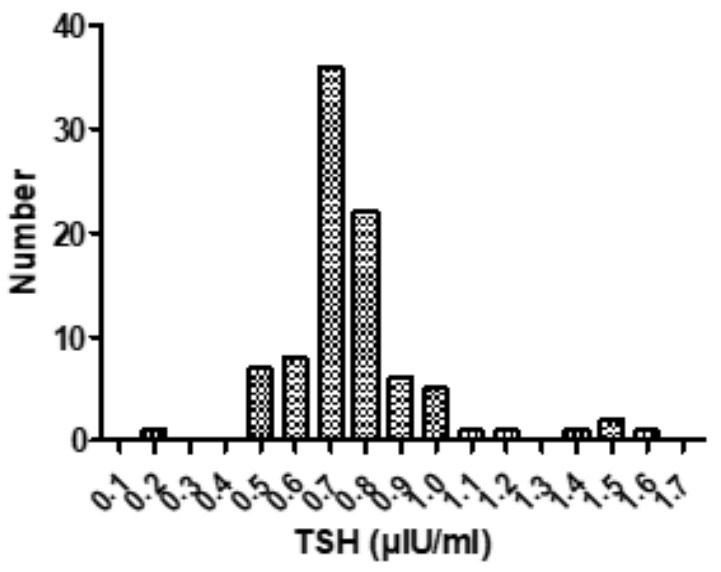

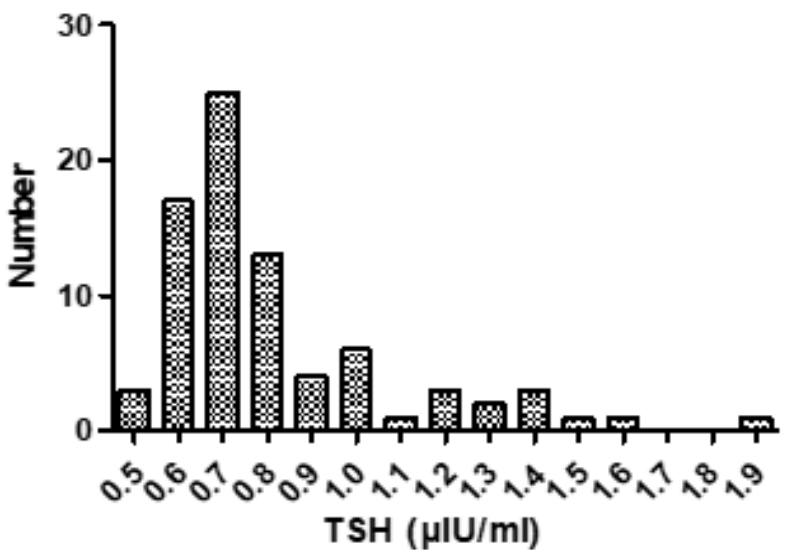

Figure 1: Histograms indicating the distribution of Red Sokoto (A) and Sahel (B) goats according to their circulating concentrations of TSH

normal range of TSH concentrations in Red Sokoto was lower than that of Sahel goats $(0.50-1.50$ vs $0.51-1.56 \mu \mathrm{lU} / \mathrm{ml})$. The distribution of Red Sokoto and Sahel goats with respect to their TSH concentrations (Figures 1 and 2) showed more skewed distribution, but lower kurtosis in Sahel than Red Sokoto goats.

Effects of age and sex on circulating concentrations of TSH in Red Sokoto and Sahel goats during the CDS, HDS and RAS are presented in Tables 3 and 4, respectively. In Red Sokoto goats, significantly lower $(P<0.05)$ value of circulating TSH was observed in kids compared with adults during the RAS and in the overall data. Similarly, in Red Sokoto goats, serum TSH concentration was significantly higher $(\mathrm{P}<0.05)$ in males than in females during the HDS.

There was no significant difference between age groups and sexes in the values of circulating TSH in Sahel goats. The effects of breed and season on circulating concentration of TSH in buck-kids and doelings are shown in Figures 3 and 4, respectively. The circulating concentration of TSH was significantly lower $(P<0.05)$ in Red Sokoto than Sahel goats during the HDS in buck-kids, while in doelings, the value was higher $(P<0.05)$ in Red Sokoto than Sahel goats. In buck-kids of Sahel goats, serum concentration of TSH was significantly lower $(P<0.05)$ in the RAS compared with the CDS and HDS. While in doelings of Sahel goats, serum concentration of TSH was significantly lower $(P<0.05)$ during the HDS compared with the RAS.

Figures 5 and 6 show the effect of breed and season on circulating TSH concentration in adult bucks and

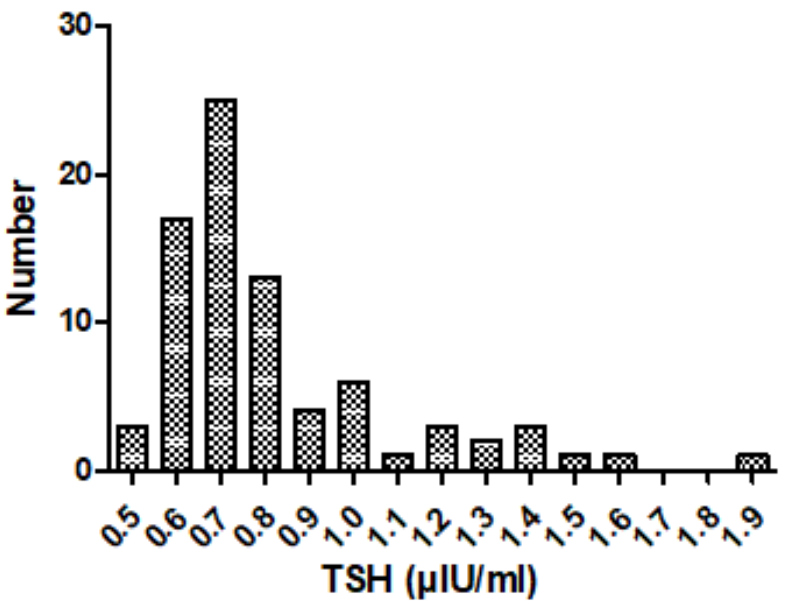

Figure 2: Histogram indicating the distribution of both Red Sokoto and Sahel goats according to their circulating concentrations of TSH

does, respectively. Like in the kids, significant effect of breed on circulating TSH concentrations in adult goats was only observed during the HDS. Circulating concentration of TSH was significantly higher $(\mathrm{P}<$ $0.05)$ in Red Sokoto than Sahel goats during the HDS in bucks, while in does, the value was lower $(P<0.05)$ in Red Sokoto than Sahel goats. Similarly, significant seasonal variation was observed only in male Sahel goats. The buck-kids of Sahel goats had significantly lower $(P<0.05)$ serum concentration of TSH during the RAS compared with the CDS and HDS, while the adult bucks had higher $(P<0.05)$ values during the RAS as compared with the HDS. 
Table 3: Effect of age on serum concentration of TSH ( $\mu \mathrm{lU} / \mathrm{ml})$ in Red Sokoto and Sahel goats in different seasons

\begin{tabular}{lcccc}
\hline Season & \multicolumn{2}{c}{ Red Sokoto } & \multicolumn{2}{c}{ Sahel } \\
\cline { 2 - 5 } & Young & Adult & Young & Adult \\
\hline Cold-dry & $0.73 \pm 0.02$ & $0.77 \pm 0.02$ & $0.98 \pm 0.01$ & $0.75 \pm 0.02$ \\
Hot-dry & $0.74 \pm 0.02$ & $0.73 \pm 0.03$ & $0.76 \pm 0.04$ & $0.72 \pm 0.04$ \\
Rainy & $0.69 \pm 0.05^{\mathrm{a}}$ & $0.93 \pm 0.10^{\mathrm{b}}$ & $0.81 \pm 0.09$ & $0.92 \pm 0.09$ \\
Total & $0.72 \pm 0.02^{\mathrm{a}}$ & $0.81 \pm 0.04^{\mathrm{b}}$ & $0.80 \pm 0.04$ & $0.81 \pm 0.04$ \\
\hline
\end{tabular}

Values of the same parameters with different superscripts $(a, b)$ are statistically significant $(P<0.05)$.

Table 4: Effect of sex on values of serum TSH ( $\mu \mathrm{IU} / \mathrm{ml})$ in Red Sokoto and Sahel goats in different seasons

\begin{tabular}{lcccc}
\hline Season & \multicolumn{2}{c}{ Red Sokoto } & Male & Female \\
\cline { 2 - 5 } & Male & Female & $0.89 \pm 0.06$ & $0.85 \pm 0.08$ \\
Cold-dry & $0.76 \pm 0.02$ & $0.75 \pm 0.02$ & $0.77 \pm 0.05$ & $0.71 \pm 0.04$ \\
Hot-dry & $0.77 \pm 0.03^{\mathrm{a}}$ & $0.70 \pm 0.02^{\mathrm{b}}$ & $0.78 \pm 0.09$ & $0.93 \pm 0.08$ \\
Rainy & $0.80 \pm 0.06$ & $0.81 \pm 0.09$ & $0.81 \pm 0.04$ & $0.81 \pm 0.04$ \\
Total & $0.78 \pm 0.03$ & $0.76 \pm 0.04$ &
\end{tabular}

Values of the same parameters with different superscripts $(a, b)$ are statistically significant $(P<0.05)$.

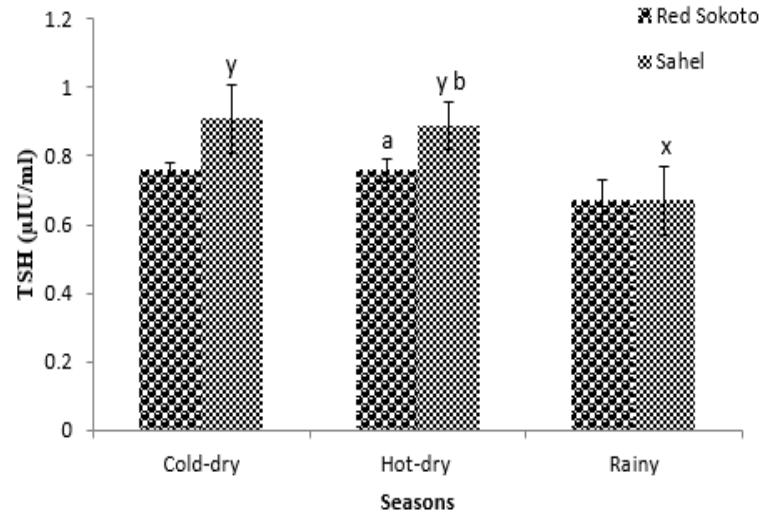

Figure 3: Effects of breed and season on circulating concentrations of TSH in buck-kids. Bars with different alphabets are statistically significant $(P<$ $0.05)$ for breeds $(a, b)$ and seasons $(x, y)$

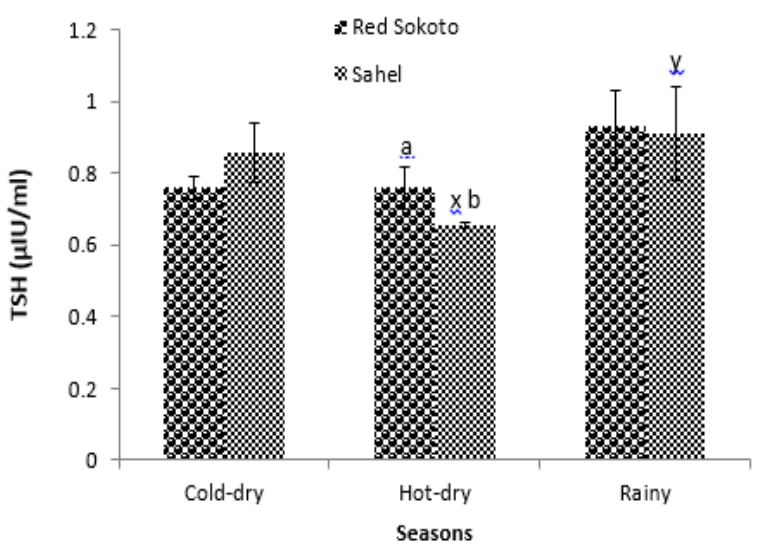

Figure 5: Effects of breed and season on circulating concentrations of TSH in adult bucks. Bars with different alphabets are statistically significant $(P<$ $0.05)$ for breeds $(a, b)$ and seasons $(x, y)$

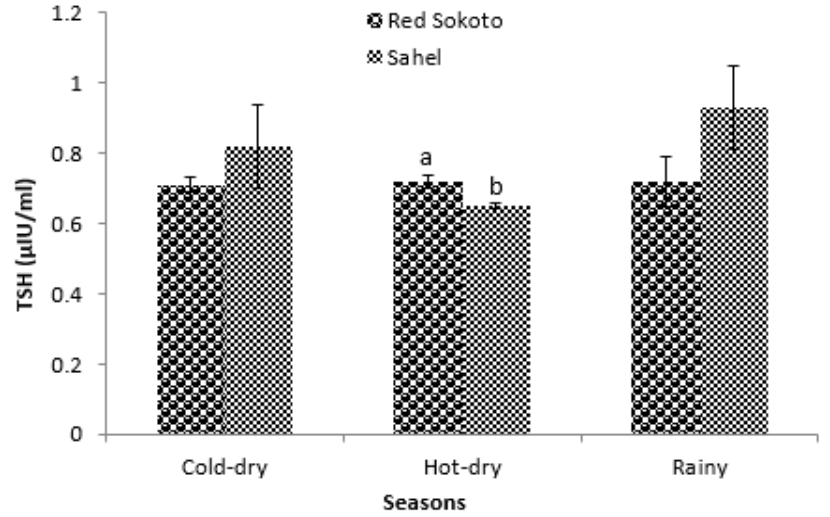

Figure 4: Effects of breed and season on circulating concentrations of TSH in doelings. Bars with different alphabets are statistically significant $(P<0.05)$ for breeds $(a, b)$

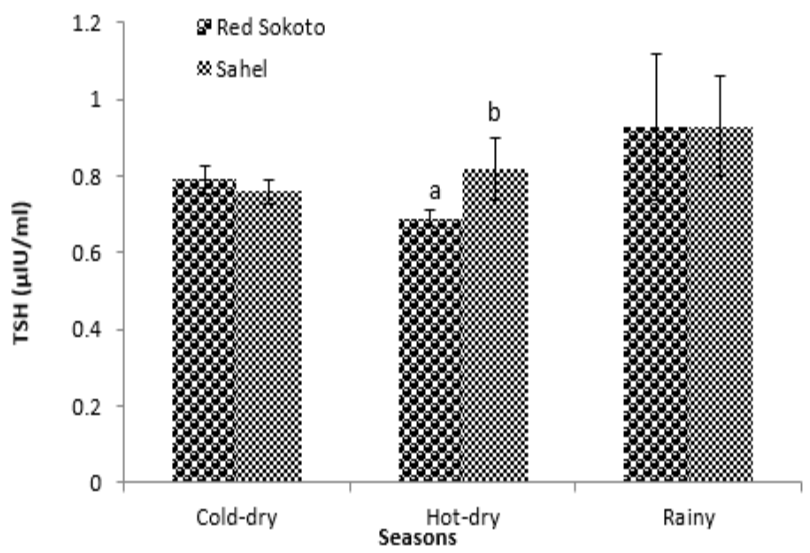

Figure 6: Effects of breed and season on circulating concentrations of TSH in adult does. Bars with different alphabets are statistically significant $(P<0.05)$ for breeds $(a, b)$ 
The association between BMI and circulating concentrations of TSH in young and adult goats are presented in Table 5, while the overall association between BMI and circulating concentrations of TSH is presented in Figure 7. A significant positive correlation ( $r=0.29 ; \mathrm{P}<0.001)$ was observed between TSH concentration and $\mathrm{BMI}$ in the overall population. Significant $(P<0.05)$ correlation was only observed in kids with the correlation being positive ( $r$ $=0.62$ ) during the HDS in Sahel goats, but negative ( $r$ $=-0.58$ ) during the RAS in Red Sokoto goats.

\section{Discussion}

The skewness for a normal distribution is zero, and any symmetric data should have a skewness near zero. The distribution of Sahel goats had a higher skewness and skewed to the right tail, towards the higher values. Thus, the Sahel goats had a higher mean value. Kurtosis is a measure of whether the data are heavy-tailed or light-tailed relative to a normal distribution. The high Kurtosis in Red Sokoto than Sahel goats reflects the heavy-tail in the histogram which indicates the existence of more outliers in Red Sokoto than Sahel goats. It is well established that the normal range of circulating concentration of a given biological molecule is dependent on the assay method used and the population of the subject concern (Schnabl et al., 2008). To our knowledge, values of circulating TSH concentration have not been reported in any breed of Nigerian goats.

The values reported in the current study are lower $(0.78 \pm 0.03$ vs $3.36 \pm 0.10 \mu \mathrm{lU} / \mathrm{ml})$ than those reported in Angora goats (Pehlivan \& Dellal, 2017). Assay technique, breed difference and variations in geographical adaptation may be responsible for the low mean values of circulating TSH concentration in Nigerian Savannah goats as compared to Angora goats.

In goats, meteorological parameters outside the thermoneutral zone for THI $(65-75)$ and ambient temperature $\left(24-30^{\circ} \mathrm{C}\right)$ may induce thermal stress (Lu, 1989; Hamzaoui et al. 2013). In the present study, the ambient temperature and THI were higher than the thermoneutral zone in the afternoon hours of the HDS, suggesting heat stress; while in the morning hours of the CDS, the THI was lower, suggesting cold stress. Unlike in sheep, a paucity of data exist on the influence of endogenous and exogenous factors on

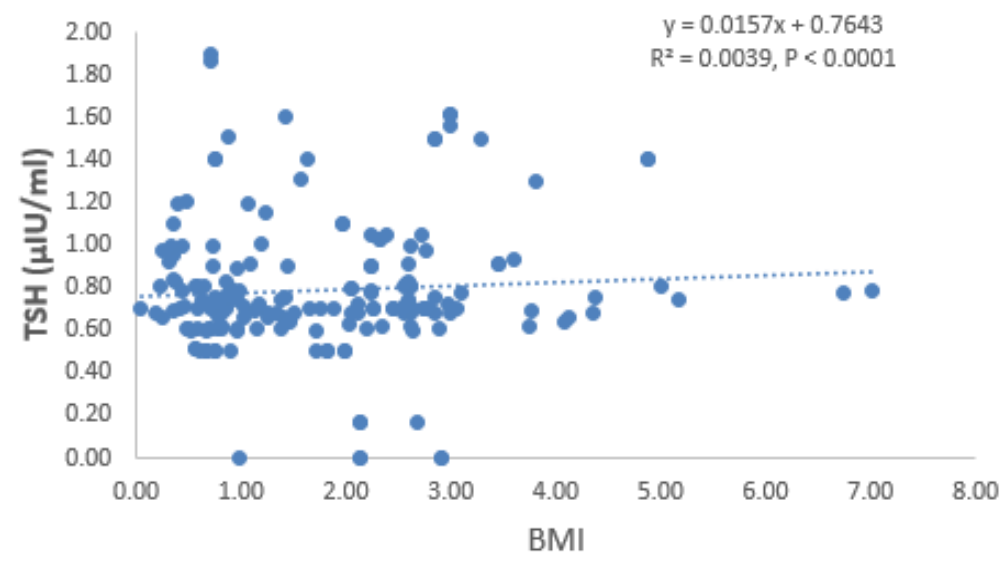

Figure 7: Overall Pearson's correlation coefficient between BMI and circulating concentrations of TSH in goats circulating levels of TSH in goats (Nouri et al., 2006; Al-Damegh, 2012). The influence of breed on the concentration of circulating TSH has been previously reported in sheep (AlDamegh, 2012). In the current study, breed difference was only observed during the HDS and the effect did not follow a definite pattern according to sex or age. Concentration of circulating TSH was higher in Sahel than Red Sokoto goats in buck-kids and adult does; while lower values were recorded in Sahel than Red Sokoto goat in doelings and adult bucks. Even though the cause of these findings is

Table 5: Pearson's correlation coefficient between BMI and circulating concentrations of TSH in young and adult goats

\begin{tabular}{lcccc}
\hline Season & \multicolumn{2}{c}{ Body mass index } & \multicolumn{2}{c}{ Adult } \\
\hline TSH & Red Sokoto & Sahel & Red Sokoto & Sahel \\
\hline Cold-dry & -0.27 & 0.241 & -0.08 & 0.35 \\
Hot-dry & -0.41 & $0.62^{*}$ & -0.17 & -0.36 \\
Rainy & $-0.58^{*}$ & 0.193 & 0.31 & 0.36 \\
\hline
\end{tabular}

Values with asterisk $\left({ }^{*}\right)$ are statistically significant $(P<0.05)$ 
not understood, this endocrine pattern suggests that breed difference in circulating TSH levels is mainly expressed when ambient heat load increases and the pattern is influenced by sex and age. Cumulatively, the endocrine pattern expressed during the HDS may reflect the challenges posed by heat stress on the hypothalamus-pituitary-thyroidal axis (Nouri et al., 2006; Habibu et al., 2017). Lesions in the thyroid gland have been reported to be more during summer than winter in apparently healthy sheep (Nouri et al., 2006).

The current study demonstrated a lower circulating TSH concentration in female compared to male Red Sokoto goats during the HDS. This suggests sexual dimorphism in the response of goats to the change in circulating TSH concentration due to effect of heat stress. Also, since the higher circulating concentration of $\mathrm{T}_{4}$ has been reported in females than males (Todini et al., 1992; Todini, 2007), it is possible that the negative feedback inhibition of TSH secretion from the pituitary may be responsible for the low TSH in females (Capen \& Martin, 2003; Todini, 2007). The findings of the current study in Red Sokoto goats disagrees with the report of Pehlivan \& Dellal (2017) in which concentration of circulating TSH did not significantly differ between male and female goats, irrespective of season. But agrees with findings of the current study in Sahel goats where sexual dimorphism was not observed in all seasons. This suggests that the expression of sexual dimorphism in TSH activity in goats may be breed and seasonal dependent.

In the current study, the lower concentration of circulating TSH in kids than adults of Red Sokoto goats is probably due to a negative feed-back effect resulting from higher concentration of circulating thyroid hormones in growing than adult goats (Colavita et al., 1983; Ashraf et al., 2021). However, the result of the current study contradicts that of Khan et al. (2001) in which circulating TSH was higher in children compared to adults; whereas, the concentration of circulating thyroid hormones was lower in children compared to adults.

On the other hand, the effect of season on concentration of circulating TSH was only expressed in the male Sahel goats, and was not observed in female Sahel and Red Sokoto goats. While the Sahel buck-kids had higher values during the CDS and HDS than the RAS, the adult male Sahel goats had low values during the HDS than the RAS. This seasonal fluctuations suggest the existence of an on-going endocrinological adaptation in the buck-kids and adult male Sahel goats due to exposure to the Guinea
Savannah climate as compared with the female Sahel and the Red Sokoto goats. The Sahel goats are indigenous to the Sahel belt of West Africa, and are until recently, adapted to the Guinea Savannah climate (Gall, 1996; Habibu et al., 2017). Similarly, previous studies have shown low adaptability of Sahel kids to the seasons of the Guinea Savannah as compared to the Red Sokoto kids (Habibu et al., $2016 a, b)$. Lower concentrations of circulating $T_{3}$ and $\mathrm{T}_{4}$ during the HDS as compared with the CDS and RAS has been reported in adult bucks of Sahel goats (Habibu et al., 2017); whereas, the values showed no significant seasonal fluctuation in kids of Sahel goats (Habibu et al., 2016a). Thus, it could be inferred that during the HDS, Sahel bucks simultaneously reduce the production of TSH and thyroid hormones to reduce thermogenic heat production and minimise the impact of heat stress (Indu et al., 2014; Gupta \& Mondal, 2019). In the Sahel buck-kids, however, the higher values of circulating TSH may reflect increased production due to reduced responsiveness of the thyroid gland to TSH resulting from heat stressinduced glandular lesions (Nouri et al., 2006) or reduction in glandular secretory activities (Ali et al., 2020). The high values of circulating TSH during the CDS may be a physiological response to cold stress; aimed at increasing production of thyroid hormones to maintain normal body temperature (Habibu et al., 2016a; Kuzmenko et al., 2021). This difference in the seasonal response of young and adult goats may be due to the weak response of buck-kids to the challenge of heat stress, given their physiological immaturity. Similarly, in agreement with the findings of the current study in Red Sokoto goats, no significant seasonal fluctuation in concentration of circulating TSH was observed in Angora goats (Pehlivan \& Dellal, 2017).

Growth is accompanied by an increase in BMI, and $\mathrm{BMI}$ is a good indicator of nutritional status or body energy reserve in animals and also shows strong direct association with body condition score (Tanaka et al., 2003: Estrada-Cortes et al., 2009; SalazarCuytun et al., 2020). In the present study, a negative association was observed between BMI and TSH concentration in young Red Sokoto goats during the RAS, while a positive correlation was observed in young Sahel goats during the HDS and the overall data. In a similar trend, Solanki et al. (2013) reported a positive correlation, while Milionis \& Milionis (2013) reported a negative correlation between $\mathrm{BMI}$ and TSH concentration in humans. The positive correlation between BMI and TSH is probably due to the role of TSH in stimulating pre-adipocyte differentiation 
which results in adipogenesis (Bell et al., 2000; Valyasevi et al., 2002; Schäffler et al., 2005). The findings of the current study suggest that circulating TSH concentrations may affect BMI and the relationship may be influenced by breed and age.

In conclusion, lower concentration of circulating TSH was observed in female compared to male Red Sokoto goats during the HDS. Similarly, breed difference was only observed during the HDS and seems to be age and sex dependent. This suggests that breed difference and sexual dimorphism in circulating TSH in these breeds is mainly expressed when the goats are exposed to high ambient heat load. Concentration of circulating TSH was lower in kids than adult Red Sokoto goats. The effect of season was age dependent, such that values were higher in young goats during the HDS and CDS, while lower values were recorded in adult goats during the HDS. The positive correlation between $\mathrm{BMI}$ and TSH is probably a reflection of its role in the accumulation of body energy reserve.

\section{Acknowledgements}

The staff of Department of Veterinary Physiology, Faculty of Veterinary Medicine as well as those of Small Ruminant Research and Biotechnology Research Programmes, NAPRI, Ahmadu Bello University, Zaria, Kaduna State gave technical assistance.

\section{Conflict of interest}

The authors declare that there is no conflict of interest.

\section{References}

Adebayo AG (1992). The Production and Export of Hides and Skins in Colonial Northern Nigeria. Journal of African History, 33(2): 2273-3000.

Ashraf M, Farid I, Shehzad W, Yousaf MR, Ahmad N, Ihsan A, Javed K, Riaz H \& Riaz A (2021). Effects of different nutritional regimens during pre-weaning period on body and testis growth, sexual behavior, hormonal profile and genes expression in male beetal goat kids. Pakistan Veterinary Journal, doi.10.29261/pakvetj/2021.023.

Al-Damegh MA (2012). Sheep breed type effects on plasma thyrotropin, thyroxine and testosterone in growing ram lambs under hot climate. Journal of Food, Agriculture and Environment, 10(3): 530-533.

Ali SA, El-Sayed SA, Goda NIA \& Beheiry RR (2020). Morphological characteristics of the goat thyroid glands among summer and winter seasons. Advances in Animal and Veterinary Science, 8(3): 252-259.

Al-Musa HM (2017). Impact of obesity on serum levels of thyroid hormones among euthyroid Saudi adults. Journal of Thyroid Research, doi.10.1155/2017/5739806.

Bell A, Gagnon A, Grunder L, Parikh SJ, Smith TJ \& Sorisky A (2000). Functional TSH receptor in human abdominal preadipocytes and orbital fibroblasts. American Journal of PhysiologyCell Physiology, 279(2): C335-C340.

Blench R (1999). Traditional livestock breeds: geographical distribution and dynamics in relation to the ecology of West Africa. Overseas Development Institute, Portland House, Stag Place, London, SW1E 5DP.

Capen CC \& Martin SL (2003). The thyroid gland. In: McDonald's Veterinary Endocrinology and Reproduction. (HP Maricio, PD Michael, editors). Blackwell Publishing Professionals, lowa, USA. Pp 35-70.

Colavita GP, Debenedetti A, Ferri C, Lisi C \& Lucaroni A (1983). Plasma concentration of thyroid hormone in domestic goat: Seasonal variations in relation to age. Bollettino della Societa`Italiana di Biologia Sperimentale, 59(6): 779-785.

Estrada-Cortes E, Vera-Avila HR, Urrutia-Morales J, Villagomez-Amezcua E, Jimenez- Severiano $\mathrm{H}$, Mejia-Guadarrama CA, Rivera-Lazano MT \& Gamez-Vazquez G (2009). Nutritional status influences reproductive seasonality in Creole Goat: 1 Ovarian activity during seasonal reproduction transitions. Animal Reproduction Science, 116(3-4): 282-290.

Ertek S (2021). Molecular economy of nature with two thyrotropins from different parts of the pituitary: pars tuberalis thyroid-stimulating hormone and pars distalis thyroidstimulating hormone. Archive of Medical Science, 17(1): 189-195.

Gall C (1996). Goat Breeds of the World. Margraf Publishing, Weikersheim, Germany. Pp 54.

Gupta M \& Mondal T (2019). Heat stress and thermoregulatory responses of goats: a review. Biological Rhythm Research, doi.10.1080/09291016.2019.1603692.

Habibu B, Kawu MU, Makun HJ \& Aluwong T (2017). Influence of seasonal changes on physiological variables, haematology and serum thyroid hormones profile in male Red 
Sokoto and Sahel goats. Journal Applied Animal Research, 45(1): 508-516.

Habibu B, Kawu MU, Makun HJ, Aluwong T \& Yaqub LS (2016a). Seasonal variation in body mass index cardinal physiological variables and serum thyroid hormones profiles in relation to susceptibility to thermal stress in goats kids. Small Ruminant Research, 145(2): 2027.

Habibu B, Kawu MU, Makun HJ, Buhari HU \& Hussaini $M(2016 b)$. Breed and seasonal variations in erythrocyte osmotic fragility of goat kids raised in semi-arid savannah. Comparative Clinical Pathology, 25(5): 1309-1312.

Hamzaoui S, Salama AAK, Albanell E, Such X \& Caja G (2013). Physiological responses and lactational performances of late-lactation dairy goats under heat stress conditions. Journal of Dairy Science, 96(10): 6355-6365.

Hassan AA \& Ciroma A (1992). Bodyweight measurements relationship in Nigerian Red Sokoto goats. Proceedings of First Biennial Conference African Small Ruminal Research Network, http://www.fao.org/wairdocs/ilri/x5520b/x 5520b1d.htm, retrieved 01-01-2015.

Igono MO \& Aliu YO (1982). Environmental profile and milk production of Friesian Zebu crosses in Nigerian Guinea Savannah. International Journal of Biometeorology, doi.10.1007/BF02184621.

Indu S, Sejian V \& Naqvi SMK (2014). Impact of simulated heat stress on growth, physiological adaptability, blood metabolites and endocrine responses in Malpura ewes under semiarid tropical environment. Animal Production Science, 55(6): 766-776.

Khan A, Akhter S, Siddiqui MM, Khan MMA \& Nawab $G$ (2001). Effect of age, sex and seasons on the concentration of thyroid and thyroid stimulating hormones. Journal of Medical Science, 1(4): 224-227.

Klein JR (2019). Novel splicing of immune system thyroid stimulating hormone $\beta$-subunitgenetic regulation and biological importance. Frontier in Endocrinology, doi.10.3389/fendo.2019.00044.

Kruger TE, Smith LR, Harbour DV \& Blalock JE (1989). Thyrotropin: An endogenous regulator of the in vitro immune response. Journal of Immunology, 142(3): 744-747.
Kuzmenko NV, Tsyrlin VA, Pliss MG \& Galagudza MM (2021). Seasonal variations in levels of human thyroid-stimulating hormone and thyroid hormones: a meta-analysis. Chronobiology International, 38(3): 301-317.

Lu DC (1989). Effects of heat stress on goat production. Small Ruminant Research, 2(2): 151-162.

Milionis A \& Milionis C (2013). Correlation between body mass index and thyroid function in euthyroid individuals in Greece. ISRN Biomarkers, doi.10.1155/2013/651494.

Minka NS \& Ayo JO (2014). Influence of cold-dry (harmattan) season on colonic temperature and the development of pulmonary hypertension in broiler chickens, and the modulating effect of ascorbic acid. Open Access Animal Physiology, doi.10.2147/OAAP.S51741.

Nouri M, Mirzadeh KH \& Mohamadian B (2006). The effect of ambient temperature on thyroid hormones concentration and histopathological changes of thyroid gland in sheep. Pakistan Journal of Biology Science, 9(12): 2308-2312.

Pehlivan E \& Dellal G (2017). Annual changes of thyroid stimulating hormone, thyroxine, triiodothyronine and cortisol hormones in angora goats. Journal of Animal and Plant Science, 27(3): 819-824.

Ravagnolo O, Misztal I \& Hoogenboom G (2000). Genetic component of heat stress in dairy cattle, development of heat index function. Journal of Dairy Science, 83(1): 2120-2125.

Salazar-Cuytun ER, Chay-Canul AJ, Ptácek M, GarciaHerrera RA, Rivera-Alegria FM, AguilarCaballero AJ \& Sarmiento-Franco LA (2020). Relationship between body mass index and body condition score in Pelibuey ewes. Ecosistemas y recursos agropecuarios, $7(2)$ : 1-7.

Santucci PM, Branca A, Napoleone M, Bouche R, Aumont G, Poisot F \& Alexandre G (1991). Body condition scoring of goats in extensive conditions. Goat nutrition. EAAP Publication, Pudoc III, Wageningen, Pp 240-256.

Schäffler A, Binart N, Scholmerich J \& Buchler C (2005). Hypothesis paper: brain talks with fat-evidence for a hypothalamic-pituitaryadipose axis? Neuropeptides, 39(4): 363367.

Schnabl K, Chan MK, Gong Y \& Adeli K (2008). Closing the gaps in paediatric reference intervals: 
the CALIPER initiative. Clinical Biochemist Review, 29(3): 89-96.

Sejian V, Bagath M, Krishnan G, Rashamol VP, Pragna P, Devaraj C \& Bhatta R (2019). Genes for resilience to heat stress in small ruminants: A review. Small Ruminant Research, 173(9): 42-53.

Smith EM, Phan M, Kruger TE, Coppenhaver DH \& Blalock JE (1983). Human lymphocyte production of immunoreactive thyrotropin. Proceedings of National Academy of Science USA, 80: 6010-6013.

Solanki A, Bansal S, Jindal S, Saxena V \& Shukla US (2013). Relationship of serum thyroid stimulating hormone with body mass index in healthy adult. Indian Journal of Endocrinology Metabolism, 17(1): 167-169.

Tanaka T, Yamaguchi T, Kamomae H \& Kaneda H (2003). Nutritionally induced weight body loss and ovarian quiescence in Shiba goats.
Journal of Reproduction and Development, 49(49): 113-119.

Todini L (2007). Thyroid hormones in small ruminants: Effects of endogenous, environmental and nutritional factors. Animal, 1(7): 997-1008.

Todini L, Lucaroni A, Malfatti A, Debenedetti A \& Costarelli $S$ (1992). Male-female differences in the annual profiles of the thyroid hormones blood level by the goat. Atti della Societa Italiana della Scienze Veterinarie, 46(1): 169-173.

Valyasevi RW, Harteneck DA, Dutton CM \& Bahn RS (2002). Stimulation of adipogenesis, peroxisome proliferator activated receptor$\gamma$ (PPAR $\gamma)$, and thyrotropin receptor by PPAR $\gamma$ agonist in human orbital preadipocyte fibroblasts. Journal of Clinical Endocrinology and Metabolism, 87(5): 23522358. 